\title{
Unnoticed and unloved: The indigenous storyteller and public theology in a postcolonial age
}

\author{
Author: \\ Edward P. Wimberly ${ }^{1}$ \\ Affiliation: \\ ${ }^{1}$ Interdominational \\ Theological Center, Atlanta, \\ USA \\ Correspondence to: \\ Edward Wimberly \\ Email: \\ wimberlyedwanne@aol.com \\ Postal address: \\ 700 Martin Luther King \\ Jr. Drive, Atlanta, Georgia \\ 30314, USA \\ Dates: \\ Received: 03 Mar. 2011 \\ Accepted: 23 Oct. 2011 \\ Published: 12 Dec. 2011 \\ How to cite this article: \\ Wimberly, E.P., 2011, \\ 'Unnoticed and unloved: \\ The indigenous storyteller \\ and public theology in a \\ postcolonial age', Verbum \\ et Ecclesia 32(2), Art. \#506, \\ 9 pages. http://dx.doi. \\ org/10.4102/ve.v32i2.506 \\ Note: \\ A version of this paper was \\ presented at a conference on \\ theology and violence, held \\ by the Faculty of Theology at \\ the University of Pretoria on \\ 10-12 August 2010
}

(C) 2011. The Authors. Licensee: AOSIS OpenJournals. This work is licensed under the Creative Commons Attribution License.
The purpose of this paper was to present a commentary on my longstanding practice, as an African-American pastoral theologian, of utilising the ethnographic qualitative research approach centring on Black masculinity and violence. My goal was to comment on what I experienced, learned, practiced and published about violence as an African-American man who happens to be a pastor, pastoral counsellor, licensed marriage and family therapist, and teacher of pastoral care and counselling for over 40 years. My method of data collection for my research and writing has been ethnographic listening to the stories of African-Americans within families and small groups, and in churches, workshops and classrooms. There is a major limitation to this approach because ethnographic research is socially and culturally located and confined to the United States of America and to the African community. Yet, my published reflections as a pastoral theologian on violence over the years were presented to stimulate conversation and discussions in the cross-cultural contexts of students, faculty and interested publics within seminaries universities and churches, particularly in South Africa, Zimbabwe and Ethiopia where I have lectured and taught.

Violence in this paper was understood as being adversarial, behavioural, physical, verbal and nonverbal, exploitive and combative reactions to very powerful economic and socio-cultural values which exist globally. These values recruit and reduce all human beings from all social strata into commodity-orientated and commercialised economic definitions of human worth. Human identity and dignity are defined exclusively by the possession of wealth, social status, privileged position, power and prestige. Those who lack such so-called honourable designations and characteristics are deemed worthless, invisible and unlovable. To be poor in this orientation means to be completely worthless and valueless. Therefore, the paper proposed an indigenous narrative storytelling model which could be used to orientate people publicly to the appropriate source of human worth and dignity.

\section{Introducing indigenous public storytelling}

The root of my investigation into the development of an indigenous storytelling model lies in a pleasant visit I had from a former student. Three years prior to this visit, that student had served two years in prison for a white-collar crime. He came in to talk with me to share what he had learned from his prison experience, the first of which was how he had survived in prison. He said to me it had been because he was a minister. He had helped the prison inmates to earn their General Education Diploma (GED), or high school diploma, an achievement which the inmates valued. Secondly, he had learned that his experience of public shame became an opportunity for God; God was forming and shaping him for future ministry. Since his release from prison, government agencies and foundations have been pursuing him for his knowledge and understanding of how to restore inmates to the community. Given the high rate of incarceration of African-American men, it is important to address the relational needs of inmates. For him, helping inmates restore relationships with their families and the community is a major key to rehabilitation, for he found that it was these communities and families themselves who were reluctant to accept the exoffender back into their lives.

Thirdly, relating directly to the inmates taught him about the connection of rap music to the Black inmate population. From the inmates' point of view rap music was their creation. They saw it as a protest against being unnoticed and unloved by society. Through rap music, they sought to make society notice them by communicating to society that they were not powerless. Rather, their power was in their ability to shape the lives of young people of all races and cultures. The music, the beats and the lyrics were all created to capture the attention of a society that regards them as invisible. In short, my former student sees his imprisonment as a renewal of his call to ministry. His vocation is to tell the inmates' stories. His calling is to tell the stories that would lead society to focus on restorative justice. His given task is to retell the stories that would, in essence, recreate the village. Because of his prison experiences he became an indigenous storyteller; prison helped 
to form him into a person with the capacity to tell the story of the relational needs of inmates and their families.

I use the visit from this former student to highlight the role of the indigenous storyteller in public theology. Public theology is about bringing into public awareness how conversations and discourses at the public level influence the lives of every person who overhears these conversations (Wimberly 2006). What many inmates hear in conversation is that human worth is market driven and, unless one has wealth, people are not acknowledged as human beings. In fact, inmates in prison have internalised these conversations, one of which is that their significance as human beings rests on being noticed at some level. Thus, rap music has become the performance genre for them to make known their impact on society. Rap music is their way of saying they have worth, power and agency. In this context, the role of the storyteller is to be a public critic, as summarised in the following quotation:

The public theologian, also drawing on faith perspectives about human worth and experiences in pastoral counseling and psychotherapy, becomes a public critic promoting noncommodity-oriented images of human worth that can provide resources for public policies and planning.

(Wimberly 2006:129)

Thus, my former student is a public theologian who is telling his story to anyone who will listen. His message is simple: the major task of the church, as well as the public theologian, is to restore lost village functions. One avenue is through attending to the relational needs of inmates. This exoffender helped me to envision the role of pastoral theology in restoring the relational aspects of village functions. The role of the indigenous storyteller in pastoral theology is to proclaim to wider society that relationships are the key to vital life and meaning for all. Through storytelling, we remind the public that relationships amongst people are what create culture. Without attending to the quality of relationships between people, life has no meaning. We need to warn people that crime and violence today are relational problems, which are rooted in feelings of being unnoticed, unloved, and uncared for.

\section{Evidence-based support for narrative approaches}

My basic approach to violence has mainly involved ethnographic listening similar to the above case. I have also drawn on key literature regarding African-American life as published in journals, novels by African-American authors, as well films which portray African-Americans as central characters. In addition, I have published many articles on violence over the years (Wimberly 1982, 1993, 1997a, 1997b, $2000,2005,2007,2010,2011)$ and these have served as rich data sources for the reflections in this paper.

Ethnographic listening as a qualitative research method is described by Mary C. Moschella (2008) as a pastoral practice which seeks to understand how people practice their faith. It is all about 'recording your observations and reflections, analyzing them and creating a narrative account' (Moschella 2008:4). Much of my own research can be described as ethnographic listening, in the sense that I have collected case studies relating to African-American men and domestic violence and sought to understand them by bringing an interdisciplinary perspective to the data I have collected.

Robert C. Dykstra (2005), in his book Images of pastoral care: Classic readings, has described what he calls the indigenous storyteller. He focuses on the fact that African-American ministers have developed a storytelling heritage for 'communicating the gospel from the pulpit and how stories have come to serve individuals, couples, and families in pastoral care and counseling' (Dykstra 2005:155). He also talks about how the storytelling tradition has been affirmed for a long time amongst 'many indigenous communities as the healing power of "storying" one's faith and life' (Dykstra 2005:155) and goes on to describe how building stories for the practice of pastoral counselling serves to sustain a long held African-American church tradition (Dykstra 2005:186). From my point of view, ethnographic listening to the stories of parishioners, who have come to me for individual, marital and family counselling, and group counselling, become what narrative researchers call 'field texts' (Clandinin \& Connelly 2000:92). Field texts are sources of research data that come from listening and writing down the stories of people and it is out of reflecting on these stories and experiences that meaning, insights and interpretations emerge. Thus, field texts comprise recorded stories, autobiographical writing, journals, oral histories, field notes, conversations, participant letters and ethnographic reflections or research documents (Clandinin \& Connelly 2000:95). They eventually become research texts from which organised reflections and interpretations of the researcher's derived meaning occur. Clandinin and Connelly (2000:132) inform us that a 'research text looks for patterns, narrative threads, tensions, and themes' that emerge from the field texts. My insights and conclusions about violence have emerged principally from my own use of the research methodology of ethnographic listening and reflections on field texts and research texts in light of an interdisciplinary approach. More specifically, I have employed a pastoral theology narrative approach which moves from listening to stories to identifying problems to reflecting on these problems in light of interdisciplinary knowledge which can be used to intervene in problems and foster change. This paper, then, is the demonstration of how I derived insight about violence from ethnographic listening and used this to design an approach for public storytelling. The best example of how I employed ethnographic listening, field texts and research texts can be seen in my work entitled, Recalling our own stories: Spiritual renewal for religious caregivers (Wimberly 1997b).

To address the concerns of 'hardcore' research empiricists who expect statistical links between dependent and independent variables, the ethnographic methods I have employed over the years are qualitative and are not qualitative. Ethnographic research is exploratory in nature. Variables and hypotheses leading to empirical conclusions can be generated through such research, but the testing of such statistical correlations still needs to be done. Moschella (2008:208) provides another caution about ethnographic 
research by arguing that pastoral ethnography is an art and not a science and she concludes that 'pastoral ethnography is adaptive in that it involves recognizing and getting on board with the wisdom that emerges in the faith community.' Such communal wisdom was critical to the Civil Rights Movement in the USA, as well as to the leadership of that movement. Dr Martin Luther King Jr, the central leader of the much of the African-American community at the time, inspired the faith community through preaching and storytelling, which eventually led public federal officials to enact policy legislation at both federal and local levels. Whilst the connection between storytelling, public policy and ethnography are not scientifically verified, the use of ethnography methods to ascertain research variables and hypotheses for further research is a legitimate research strategy.

\section{The connections between violence and self-perception Violence and the state of being unnoticed}

The above story regarding inmates is not just about the agency and recognition that come from rap music; it is also about violence. Some rap music is all about being recognised and being respected as men, particularly amongst peers and women. In 1994, William Oliver wrote an evidence-based book entitled, The violent social world of Black men. In it, he introduced the concept of 'compulsive masculinity', which referred to the way Black men constructed exaggerated images of what it meant to be men. More precisely, he points out that compulsive masculinity is about distorted images which form a nonhuman and unrealistic picture of persons. Such persons are depicted as having the capacity to transcend tragedy and social oppression through cutting themselves off from their emotions in order to feel that they are invulnerable and therefore incapable of being hurt (Oliver 1994).

Compulsive masculinity is also linked to internalised images of what constitutes manhood. These images are also socially constructed and inform whether or not violence is utilised to demonstrate one's manhood. Commenting on Oliver's understanding of compulsive masculinity, I argued the following in an article entitled, 'The men's movement and pastoral care of African American men':

Compulsive masculinity is defined as masculine behavior characterized by toughness, sexual conquest, manipulation, and thrill-seeking. It is 'the belief that toughness -physical prowess, emotional detachment, and willingness to resort to violence to resolve interpersonal conflicts - is an omnipresent characteristic of masculinity.

(Wimberly 1997c:118)

The significance of compulsive masculinity is the reality of the need to appear 'cool' or to establish the 'cool pose' in the eyes of female peers, which extends to mothers and grandmothers. This is significant because women 'keep men connected to their vulnerability and feelings' (Wimberly 1997a:18). In this context:
Women are to be conquered, exploited sexually and subjugated to men. The rap music that portrays females as whores and female dogs (bitches) is but one example of this attitude.

(Majors \& Billson 1992)

There is evidence-based research showing that isolating oneself from one's emotions contributes to violence. In 1993, The Urban League Review: A Policy Research Journal of the National Urban League was dedicated to 'African American males: A critical link in the African family'. This edition of the Urban League Review links violence to what some call 'coolin'. Violence is the ultimate way of being cool because it says a man is not afraid to kill or die. Yet, when 'coolin' becomes the focus, there is a notable absence of a healthy perspective on vulnerability or living creatively in community; there is no sense that community is the real source of what it means to be a man. In short, Victor De La Cancela (1993), drawing on the evidence-based research of Majors and Billson, says the cool pose:

is defined as a ritualized masculinity entailing scripts, posturing, impression management and other carefully constructed performances that present the male as proud, strong, and in control. The 'cool pose' makes African American males noticeable and visible, but it hides insecurity, vulnerability, and rage, and these feelings cause black males to distance themselves from others and alienate them from deeper motives.

(De La Cancela 1993:33)

Thus, the cool pose is linked to the need to be seen as strong and powerful, two characteristics that are equated with being loved. Moreover, violence is associated with respect, status and power.

Behind this view of violence is the feeling of being unnoticed or invisible, particularly in wider society. Moreover, being recruited into negative images of what it means to be a man is better than being unnoticed. Thus, being remembered for killing, dying or abusing women, at least in the minds of those who have internalised compulsive masculinity, is better than remaining unrecognised. The point is that for Black men, both the state of being unnoticed and the desire to be noticed are sources of senseless violence, including Blackon-Black violence.

\section{Violence and the state of being unloved}

As we can see from above, the connection between Black men and violence is primarily centred on the state of being unnoticed. However, the connection between violence and women in the African-American community focuses largely on the state of being unloved, as demonstrated powerfully in the 2009 film entitled, Precious. This provocative and soulsearching film is a field text on relational and intimate violence. Precious is based on the novel Push by Sapphire. In this film, there is a scene where Mary, played by Academy Awardwinning actress Mo'Nique, is portrayed as a dysfunctional and abusive mother. In this particular scene, Mary explodes in violence against her daughter and grandson asking the question: 'Who is going to love me?' Her daughter, Precious, played by Gabourey Sidibe, was a two-time rape and incest victim of her father. She had one child and was pregnant with 
another as a result. Feeling betrayed by her own daughter, whom she obviously expected to love her and be a source of love, Mary exclaims 'who will love me?' This question is similar to the Black male question of 'who will notice me?' Yet, it is also different, in that it is related to the images of female beauty esteemed as the norm by wider culture. Mary turned to violence against her daughter, believing that she herself is unlovable and this conviction of being unlovable and worthless was related to her being unable to meet the norms of beauty held by society.

In another scene, Precious was able to escape some of the trauma caused through violence and abuse by turning to imagination and fantasy. Whilst being raped, she imagines herself in a music video where she is the centre of attention. She also images that she is White, thin and blonde. In this fantasy world she is loved and appreciated. The movie is an excellent example of the theme of shame, which I define accordingly as the feeling of being both unloved and unlovable. From this definition, shame can be seen as the source of violence for some Black women. Their violence is the lashing out toward themselves or others based on the belief that they will never be loved or accepted.

The above filmic analysis is not evidence-based in the empirical research sense; rather, it is a conviction about the significance of stories as field texts that I have developed from my ethnographic experience as a pastoral counsellor practitioner for over 40 years. As part of my use of the ethnographic method, I have relied on the pastoral theological methodology known as revised critical correlation to reflect on the significance of African-American novelists in lending evidence-based credence to some conclusions about certain repetitive or repeating literary patterns and themes which appear in their novels. By revised critical correlation, I mean the act of looking to secular novels for answers to some theological questions which compare with, or have coherence with, theological answers found in our faith heritage in the Bible and related doctrine. With regard to the role of critical correlations in African-American novels, I propose the following:

By way of summary, revised critical correlation helps us draw out the wisdom from the novel which we can use to intervene in the lives of our counselees. Therefore, we need to be alert when certain symbolic patterns emerge. When certain symbolic and mimetic patters appear, we learn to recognize them immediately, as a result of revised critical correlations. This method of reflecting helps us visualize that significant spiritual and theological conversation is taking place. We become aware that we are about to launch into potential transforming dialogue with the counselee.

(Wimberly 2003b:34)

Whether one is an African-American man who is convinced that he is unnoticed and that only compulsive and violent masculinity is the answer to such invisibility, or whether one is an African-American woman who is convinced that she is unlovable and therefore turns to self and/or other violence, these convictions are the source of both the destruction of self and community. Thus, these sources of violence need to be put into their proper context so that pastoral theology can design strategies and practices to address the violence that results from being unnoticed and unloved.

\section{Contextualising the violence}

One of the tasks of pastoral theology is to put the problem of being unnoticed and unloved into its cultural context. According to Alain de Botton (2004) in his work Status anxiety, being unnoticed produces rage and impotent despair. For him, the number one motivating factor today is the striving for recognition through material status. Those who do not possess it go unnoticed, which means that the poor are nonexistent and invisible. Quoting William James's 1890 work, Principles of psychology, De Botton says that we live in a culture that bestows identity, worth and dignity through material wealth. To be without wealth is to endure a fiendish punishment:

No more fiendish punishment could be devised, were such a thing physically possible, than that one should be turned loose in society and remain absolutely unnoticed by all the members thereof. If no one turned around when we entered, answered when we spoke, or minded what we did, but if every person we met 'cut us dead,' and acted as if we were non-existent things, a kind of rage and impotent despair would before long well up in us, from which the cruelest bodily torture would be a relief.

(James, cited in De Botton 2004:8)

What a fitting commentary on our culture today. I think that this has credence not simply for those who live in the USA, but also for those who live in post-apartheid South Africa. Firstly, to summarise, a lack of material status equates to nonexistence and torture would be a relief to those who do not possess it. Secondly, rage and impotence clearly go together. Thirdly, being in prison for those who are poor is better than being unnoticed and unloved.

In her paper entitled, 'Work-in-progress: A Latin American mosaic,' Janet May (2007) mentions that the gospel of prosperity was running wild and rampant in most of the churches in the countries she was describing. My own understanding is that status anxiety is a global issue and no one in any country is spared this anxiety, especially those in poorer countries, poorer communities, and certainly in the ethnic minority populations in the USA.

One way to understand the meaning of living in a postcolonial culture is the reality of the recognition that colonialism's pursuit of honour and status, through the domination of underdeveloped countries with rich resources for the purposes of becoming wealthy, is nothing more than national self-deception and an illusion (Rivera-Pagan 2007). The pursuit of wealth as the source of honour, status, love, of being noticed, and of finding meaning, is empty and meaningless. Such pursuits exacerbate the thirst for status, for being noticed, for being loved and for being regarded as beautiful, rather than satisfying these needs. In other words, the inability to find satisfaction in the pursuit of wealth, love, notoriety and beauty stimulates more violence amongst 
those who seek identity and meaning through material wellbeing. It causes more violence, greed and unlawful schemes to achieve wealth.

What is even more significant is De Botton's (2004) analysis of status anxiety. For him, status anxiety is the fear that one will be stripped of dignity and worth if one does not have the material wealth to be recognised. Even more profound is his conviction that the pursuit of wealth is not our primary need as human beings. He says the need for wealth is created and grows out of the material success of the USA as a nation. For him, then, the pursuit of worth and dignity through material wealth is a substitute for the pursuit of love: 'Money, fame, and influence may be valued more as tokens of - and means to love rather than ends in themselves' (De Botton 2004).

The killings at Columbine High School and at Virginia Tech University in the USA are all protests about the fact that culture says persons are not loved unless they have wealth. It is not just the Black youth and young adult men who are violent. Any persons, regardless of colour or ethnic origin and including those in power, are at risk of using violence to achieve the rewards associated with wealth. Even amidst one of the worst world financial disasters in history, many heads of financial firms are returning to the failed strategies that led to the financial meltdown in the first place. It seems that the quest for wealth as a source of meaning, identity and power is so powerful that we cannot save ourselves from destruction and death. Those in our prisons, both the once-wealthy and the poor, are showing us that all efforts to achieve meaning, power, identity and worth through wealth will fail.

If being noticed is connected to being wealthy, and if ethnic minorities and poor populations are cut off from such wealth, then there are several avenues that can be taken to remedy the lack of wealth and recognition. For example, going into the rap music and entertainment business is one option. Yet, the connection of violence with some rap music, as well as the risk of being exploited by the powerful music industry, is well known. For example, in an article entitled 'Is corporate America to blame for hip-hop violence?', Jake Tapper and Marie Nelson (2005) point out that criminal activity is becoming rap music's selling point. They argue that Rev. Al Sharpton, who is a prominent Civil Rights activist in the USA, is on a crusade to address publicly violent criminal acts which are the major selling points to promote the industry by saying: 'I think that that is the wrong signal to send to young Americans' (Tapper \& Nelson 2005). Rev. Sharpton implicates the fact that corporate America helps to promote violence through its promotion of hip-hop. For me, his claim raises the question: is this a stretch of the truth or is there some reality in his thinking? In seeming response to that question, as early as 1963, Erik Erikson in his book, Childhood and society, pointed out that there were three identities into which African-Americans were recruited by wider society:

Three identities are formed: (1) mammy's oral-sensual 'honey child', - tender, expressive, rhythmical; (2) the evil identity of the dirty, anal-sadistic, phallic-rapist 'nigger'; and (3) the clean, anal-compulsive, restrained, friendly, but always sad 'white man's Negro'.

(Erickson 1963:242)
Indeed, it appears that the negative identities into which African-American youth are recruited continue to exist and corporate America is clearly helping to promote the 'evil identity of the dirty, anal-sadistic, phallic-rapist nigger'. Not only is there an apparent adoption of the image of the criminal and gangster Black male but there is also the recruitment of Black women into lifestyles that lead to incarceration, drugs, poverty and unemployment (Wimberly 1993). The point is that such avenues eventually lead to death and destruction.

We have a responsibility in our storytelling approaches in pastoral theology to proclaim that there is the propensity of persons to look for love in all the wrong places, as the tragic death of famed model, Anna Nicole Smith, seems to suggest. Moreover, as pastoral theologians and counsellors, we need to proclaim that love means being connected to positive communal relationships and a relationship with God. Pursuing wealth as a source of love produces nothing but status anxiety.

\section{Biblical and theological views on status anxiety}

Status anxiety is neither a new nor modern concept. It is part of our sinful nature as human beings. In the biblical story of Job, Job's chief lament was not that he had lost his family or his wealth; his major complaint was that he lost his status in the marketplace. In Claiming God, reclaiming dignity (Wimberly 2003), I point out that the pursuit of honour for Job was all about the respect that he felt in the marketplace. If there was a sin in Job's life, it was the fact that he relied on the honour bestowed by the marketplace too much. The extent to which Job is given honour in this regard is revealed in Job 29. This chapter begins with Job's remembrances of the past where he had a premier place in the public square and marketplace (v. 7). When he came into the public area, young men withdrew and old men stood in respect (v. 8). Royalty stopped what they were doing (v. 10). He was able to respond to the needy, including the fatherless and widows (vv. 12-13). He was the eyes of the blind and the feet of the lame (v. 15). Job was in his glory (v. 20) and his honourable status was permanent, something he would take to his grave (Wimberly 2003:118).

In my 2003 work, I go on to say that Job's status in the marketplace was not permanent. Rather, in Job 30, he complains severely about his loss of status in the marketplace. He was shunned, mocked and unnoticed. Indeed, his lament was about his loss of status; but, the conclusion of the Book of Job confirms De Botton's (2004) thesis, that is, his real pursuit was not for status or wealth. Rather, his pursuit was for love and for a relationship with God. One perspective is that the Book of Job should have ended with God appearing and sharing fellowship with Job, rather than in the restoration of his wealth. From this view, the conclusion took away the major point of Job. My own view is that the major point of the Book of Job centres on finding the true source of love, which is our fellowship with God.

A second biblical and theological view on the sin of seeking honour in the marketplace is found in Robert Jewett's (2007) 
intriguing analysis of Paul's understanding of the flesh in his work, Romans. Paul's analysis of the flesh in Romans 7:5 is related to the pursuit of honour and dignity and public recognition at the expense of others. Flesh is not best understood as the satisfaction of our sensual desires. For Jewett, the flesh was the desire to surpass others in the search of honour. To seek honour put us in opposition to God's will (Jewett 2007). Paul goes on to talk about the fact that death is the fruit of the pursuit of honour. In fact, the fruit is none other than slavery. Jewett (2007) comments on the significance of being set free from the law which has its roots in the pursuit of honour:

Since Christ died as a victim of the law, revealing the lethal implications of its perversion into a system of gaining precedence over others, to accept the Gospel is simultaneously to be set free from the compulsion to perform and to compel others to conform. It is to abandon any further efforts to gain honor through meeting the law's demands. Under the aegis of grace, the need for honor has been met and the compulsion to obey the law, in whatever form it appears, is removed from its motivating power. By participating in the death of Christ, believers have 'died' to that by which they were confined.

(Jewett 2007:437-438)

The point is that to pursue love through the pursuit of wealth and public recognition is to miss the mark. Cultural systems of honour and shame lead to death and slavery. Thus, the role of the pastoral theologian is to be the indigenous storyteller who proclaims the danger of raising honour to the status of a god. The indigenous storyteller needs to lead persons to the true source of love, which can be found through connecting to a positive relational and cross-generational village and being in relationship to God.

\section{Indigenous storytelling methods}

So far in this paper we have talked about how prison inmates identify a connection between their lives of crime and their state being unnoticed and unloved. In this, they have learned that respect, honour, dignity, worth and love are related to being wealthy. We also concluded that the core human striving is not to be wealthy; rather, it is the drive to be loved. The source of this motivation is the fear of losing status in the marketplace. Moreover, status anxiety is not new; it has ancient roots and is found, for example, in both Job's and the Apostle Paul's experiences. Given this background, I have emphasised that the role of the indigenous storyteller is to proclaim to wider culture that the pursuit of wealth is an illusion. The accumulation of wealth will not produce life or love - it only produces violence and death. The opposite of the pursuit of wealth is the pursuit of love. It is the role of the indigenous storyteller to tell the story that the true object of our pursuits is to be found in being in positive, life-giving relationships with others and with God.

I will now explore more deeply the tasks of an indigenous storyteller in recreating village functions in a postcolonial society. Firstly, African-American storytelling took place outside of mainstream North American society. It grew out of a creative effort of slaves and former slaves to counter the negative labelling and racist attitudes of the wider culture in which they found themselves. Thus, through the imaginative use of biblical stories, as well as secret meetings, they developed their capacity to determine their own worth, value and dignity. The slaves and ex-slaves knew that their worth, dignity and value were gifts from God. They skilfully retold biblical stories and their own stories about how God loved them, despite their ascribed low status in culture. They found alternative metaphors and interpretations that both raised their worth and value and showed those within the slave and ex-slave community how to pursue dignity and worth. The story listeners were told that they needed to have a personal relationship with God. They were also told that they needed to belong to God's family. Moreover, they learned that they were accountable to God for how they lived with one another. Graphic stories were told about the limitations of the pursuit of material wealth. Stories were told about the useless pursuit of dignity and worth through the 'almighty' Dollar. They were told that money had its place; yet, they also were told that the love of money was the root of all evil. Although status and honour were important, they had to be weighed against God's call to service.

Secondly, indigenous storytelling required forums and audiences, where the storytellers and others could tell their stories. In the slave community, place had to be found where the master could not see or overhear the storytellers - they needed unsupervised space. Thus, indigenous storytelling requires a safe space and a receptive audience. The need to tell stories to an audience is crucial in a society where the village has collapsed. In fact, Michael White (1997) says that finding an audience for telling one's story is difficult in contemporary life. Natural audiences do not exist as they once did. Thus, the indigenous storyteller must reach back into history and relearn the need to create an audience where stories can be told and interpreted. Such audiences can become receptive ears and places of affirmation to counter the wider cultural honour and shame system.

Thirdly, indigenous storytellers who were found in the slave community of early US history, helped people link their lives with significant stories, particularly to biblical stories and the stories of heroes and heroines from within the community. These indigenous storytellers understood the nature of how God worked through hope-filled plots. Storytellers taught others how to put their lives within plots. They taught that plots had to be lived out. You could not get ahead of what God was doing in the story; you had to be led by God. Moreover, they taught how to interpret life in light of the unfolding story. One did not look to a racist culture for cues to life; rather, one looked to God. Their stories, as found in slave narratives and songs, are resources for today.

Fourthly, we need to look for contemporary indigenous storytellers in society and they need not always be religious leaders. Today, many novelists can be called pastoral theologians because they use the pastoral theological method of revised critical correlation. That is, through their storytelling, they raise significant theological questions and, 
moreover, they provide theological answers. Thus, many are indigenous storytellers as well as pastoral theologians. For example, earlier I pointed to the effective use of contemporary novels and films as indigenous storytelling resources.

Fifthly, and finally, what distinguishes postcolonial storytelling from storytelling in the early American slave community is that postcolonial storytelling must take place in public arenas and in the marketplace. It is not enough to address only the needs of those within the village alone. Those who tell the stories to the village members must tell their stories to wider cultural audiences as well. The content of these stories must address how status anxiety, or the fear of losing one's privileged position in society, is the source of racism, sexism, homophobia, concerns about immigration, neo-colonialism and a whole host of other problems that come with seeking wealth and privilege at the expense of others.

In his acclaimed Oprah Book Club novel, A lesson before dying, Ernest Gaines (1993) tells the story of how a community loved the main character, Jefferson, into full humanity after his time in prison. Gaines asks the question: how does a community make a person into a full human being who is willing to give his or her life for others? He does not simply ask the questions in this regard, but he uses the pages of his novel to answer them as well. The answer he provides is that the community must respond in love to the inmate and help the inmate interpret his or her life in light of Scripture. Jefferson found that Jesus' death on the cross became the story and plot that made his life significant, despite his previous life.

Another indigenous storyteller and pastoral theologian is Pearl Cleage (1997), who wrote, What looks like crazy on an ordinary day, another book to be featured on Oprah Winfrey's Book Club. Through her novel, it is clear to me that Cleage is raising the question: is there life after contracting HIV and AIDS? The answer Cleage provides is 'yes' and she uses the novel to tell how the chief character, Ava Johnson, not only finds a community to love her, but also how she finds romantic love and discovers her calling or vocation when others had pronounced the end to her life.

Similarly, in his many novels, E. Lynn Harris tells stories of gay men who learn to work through the state of being devalued by society to find their dignity and worth in God and in spirituality. His major question in this regard is the title of his memoir: What becomes of the broken hearted? (Harris 2003). He begins his memoir with story about how he had prayed right before trying to kill himself with an overdose of pills. He had asked God to save him if God was truly God:

I crawled into my bed and decided to give God a final chance to perform one of the miracles I'd heard about in childhood Sunday school classes. I talked silently to God, telling him that I was ready to leave this place called earth. I asked Him to forgive me for taking matters into my own hands, but I knew He would understand my pain and knew my heart. I closed my eyes and believed I was closing them for the last time.

(Harris 2003:2)
He said that he awakened the next day covered in his own vomit and takes the act of his waking up as confirmation that God is real. He therefore began his pilgrimage of telling the story of his relationship with God and how he found confirmation of his worth and dignity in God's love.

I consider Harris's (2000) most significant contribution to be his distinction between snow and rain in his novel, Abide with me. Harris sets out to tell the story of how dignity and worth are gifts from God. The scene that is of particular importance here is a vision in a football stadium that centres on the character named Raymond. Kyle, a former friend of Raymond's who had died of AIDS, returns to give him a reality check by providing a message from heaven. In my book, Claiming God, reclaiming dignity (Wimberly 2003), I reflect on the meaning of the Harris's novel for today's society:

In Harris's narrative Kyle brings a message from God. In talking to Raymond, Kyle also tells Raymond to put his faith in God and in himself and to listen to the snow, the 'still small voice' of God. Snow symbolizes the authentic voice of God that blankets the world. This voice can be trusted. The rain, however, is the noisy voice of the world that drowns rather than blankets. The voice of snow is comforting; the voice of rain is threatening. Listening to the snow also means that God's revelation can occur more than once, and that Raymond should expect to hear from God in the future. The affirming message for Raymond is that he is not alone in his struggles. God will see him through.

(Wimberly 2003:57-58)

When the vision was almost over, and Kyle had delivered his advice, Raymond asks Kyle what heaven is like. Kyle replies that you can hear the snow. The significance of Harris's novels and memoirs is that they tell the story of how he, a gay man, worked through his own struggles with his sexual identity and ultimately found it in God's love. Although he struggled with being gay until his (recent) death, he knew God cared for him and was with him in his struggle. Harris had internalised the voices of an honour and shame culture, but through his storytelling he lets us in on how God transformed his life. He could affirm himself despite being disparaged by society.

Let me hasten to add that I am not embracing homosexuality as a lifestyle, just as Harris himself never embraced it. In fact, he asked God to deliver him from it, but he said God refused. Essentially, I find Harris's statements about homosexual or heterosexual intercourse instructive in regard to whether the act of intercourse heals or bestows identity, as the following quotation summarising Harris's legacy to public theology indicates:

E. Lynn Harris is a signature person whose novels and memoirs help us envision how faith in God and living in community with family and friends are essential to the quest for self-validation. In fact he says that celibacy and sobriety were essential in helping him make progress toward self-love. He discovered what Karen discovered. This is, he found out that sex or sexual intercourse did not bring healing or help further his quest for self-validation. It was a relationship with God and being part of a loving and caring family and community that, along with a vocation or calling, brought him to self-validation.

(Wimberly 2008:102) 
Indeed, the message of the indigenous storyteller is that we must learn to listen to the snow and not the rain. As in the biblical record, the key message is that Jesus Christ has come to overturn society's honour and shame culture. Our worth is bestowed by God. Like Paul, we need to give up the pursuits of our flesh or the desire to be affirmed by others and culture. Our value and worth can only come from God. Being members of a loving and caring community or village is essential; yet, without having a relationship with God, we cannot fully embrace God's gift of love, worth and dignity. In Romans 1:16, Paul says that he is not ashamed of the Gospel: 'It is the power of God for salvation to every one who has faith.' The Gospel shames the wise and honours the foolish. The point is that the marketplace offers an elusion, whereas the Gospel offers the real thing. We, as indigenous storytellers and pastoral theologians, must also offer the real thing.

Indigenous storytellers emerge from a community of faith. In introducing himself to the churches in Rome, in Romans 1 , Pauls says that he had an obligation to those who were in the household of God first and then to the culture at large. He also had an obligation to those within the church and outside the church who were foolish, who pursued cultural honour and public acclaim as the source of their worth and value. Moreover, Paul had an obligation to preach to the wise, who are those who have experienced the disappointment of pursuing their worth and value by cultural standards and are now looking to God. As indigenous storytellers, we proclaim that God is righteous and faithful. The result of this narrative proclamation is the realisation that God is the source of our getting up in the morning and our laying down at night. It becomes possible for the story listener to hear that God comes to us, the way God did to Harris when he despaired that culture despised him because of his sexual identity crisis and to Eva Johnson when society all but pronounced her dead because of HIV and AIDS. Similarly, the intent of indigenous storytelling is for the story listener to learn the kind of personal wisdom that was revealed in the story of when God came to Jefferson when he was in prison on death row and taught him that he was worthwhile, or when God appeared to Job at the moment of his greatest despair, or when God came to Paul at the height of his public popularity and asked him why he was fighting against God. God turned Paul away from the pursuit of his fleshly desires for honour and acclaim in the world and, in doing so, turned Paul toward seeking glory in serving God. From a personal standpoint, I must also share that God came to me as well, when the arteries in my heart were clogged after many years of pursuing honour in the marketplace. God said to me, 'you have no idea of the honour I have in store for you, because I have more work for you to do.'

Not surprisingly, the indigenous storytelling methodology is also akin to the pastoral theological method in that both address problems that need to be resolved; they bring biblical and theological perspectives into dialogue with a critical cultural contextual analysis of the problem in order to gain insight into the nature of the problem. They also both embrace strategies to solve problems that can be shared publicly with those in the faith communities, as well as with those in the wider public. The message of the indigenous storyteller and that of the pastoral theologian is that it is God who bestows on us God's honour, identity and worth. The world cannot give it to us; and the world cannot take it from us. As pastoral and public theologians and indigenous storytellers, we tell the world about God's faithfulness in bestowing on us worth and value as human beings.

Therefore, as pastoral theologians and indigenous storytellers, we publicly need to tell stories about status anxiety. For status anxiety is not only ruining the lives of poor nations and people, but it is also destroying the countries and lives of those who seek their wealth and status at the expense of others. The competition over scarce resources and the domination of others through colonialism and neo-colonial forms of government increases the anxiety for national security, rather than lessening it. Whilst our storytelling might seem to be of little consequence and even sound like nonsense to most, the pursuit of love through wealth and status permeates all class strata in societies around the world. It is essential to place the understanding of wealth and its acquisition into a proper perspective that supports human survival, whilst, at the same time, helping persons to visualise that human meaning, dignity and worth emerge from positive human relationships and faith-oriented values.

To conclude, then, this paper on violence has emerged out of employing the qualitative methods of ethnography, as well as pastoral theological methodology. Ethnographic research methods helped me to realise that I had accumulated rich field texts, the interpretations of which became the research texts for many of my books over a long time span. The insights derived from the research texts that were the result of using ethnographic listening were submitted to the scrutiny of a multidisciplinary assessment, including the behavioural and social sciences, in dialogue with theology. Following these assessments, I have drawn on pastoral theological methodology and indigenous storytelling methods to develop a practical strategy that not only addresses the needs of the church, but which also has a viable public message as well.

\section{Acknowledgements Competing interests}

The author declares that he has no financial or personal relationship(s) which may have inappropriately influenced him in writing this paper.

\section{References}

Clandinin D. \& Connelly, F., 2000, Narrative inquiry: Experience and story in qualitative research, Jossey Bass, San Francisco.

Cleage, P., 1997, What looks like crazy on an ordinary day, Avon Books, New York. De Botton, A., 2004, Status anxiety, Vintage International, New York.

De La Cancela, V., 1993, 'Coolin: The psychosocial communication of African and Latino men', The Urban League Review 16(2), 33-44.

Dykstra, R., 2005, Images of pastoral care: Classic readings, Chalice Press, St. Louis. Erikson, E., 1963, Childhood and society, W.W. Norton, New York. 
Gaines, E., 1993, A lesson before dying, Vintage Books, New York.

Harris, E., 2000, Abide with me, Anchor Books, New York.

Harris, E., 2003, What becomes of the broken hearted, Doubleday, New York.

Jewett, R., 2007, Romans, Augsburg Fortress, Minneapolis.

Majors, R. \& Billson, J.M., 1992, Cool pose: The dilemmas of Black manhood in America, Lexington Books, New York.

May, J., 2007, 'Work-in-progress: A Latin American mosaic,' paper presented at the Society for Pastoral Theology annual meeting, San Juan, Puerto Rico, 16 June.

Moschella, M., 2008, Ethnography as a pastoral practice: An introduction, Pilgrim Press, Cleveland.

Oliver, W., 1994, The violent world of Black men, Lexington Books, New York.

Rivera-Pagan, L., 2007, 'Doing theology in a post-colonial context: Some observations from the Caribbean,' paper presented at the Society for Pastoral Theology annual meeting, San Juan, Puerto Rico, 14 June.

Tapper, J. \& Nelson, M., 2005, 'Is corporate America to blame for hip-hop violence?' Nightline News, ABC News, viewed 22 April 2005, from http://abcnews.go.com/ Nightline/News/story?id $=694982 \&$ page $=1$

White, M., 1997, Narratives of therapists' lives, Dulwich Centre Publications, Adelaide.

Wimberly, E., 1982, 'A source of conflict between Black males and females', an occasional paper presented at the Institute for Religion and Wholeness in the School of Theology at Claremont, Claremont.

Wimberly, E., 1993, 'Pastoral counseling with African American men,' The Urban League Review 16(2), 77-84.
Wimberly, E., 1997a 'Compulsive masculinity and violence,' The Caregiver Journal 13(1), 18-19.

Wimberly, E., 1997b, Recalling our own stories: Spiritual renewal for religious caregivers, Jossey Bass, San Francisco.

Wimberly, E., 1997c, 'The men's movement and pastoral care of African American men', in C. Neuger \& J. Poling (eds.), The Care of Men, Abingdon Press, Nashville.

Wimberly, E., 2000, 'The Civil Rights Movement as a potential mentoring model for ending domestic abuse', Journal of Religion and Abuse (2), 33-48.

Wimberly, E., 2003a, Claiming God, reclaiming dignity: African American pastoral care, Abingdon Press, Nashville.

Wimberly, E., 2003b, 'Pastoral theological method and post-nihilism,' Journal of Pastoral Theology 1, 25-35.

Wimberly, E., 2006, African American pastoral care and counseling: The politics of oppression and empowerment, Pilgrim Press, Cleveland.

Wimberly, E., 2007, 'Exploring the meaning and possibilities of Black fatherhood today', in J.B. Hill (ed.), Multidimensional ministry for today's Black family, pp. 41-56, Judson Press, Valley Forge.

Wimberly, E., 2008, African American pastoral care, rev. edn., Abingdon Press, Nashville.

Wimberly, E., 2010, 'It's a girl: Challenges to African American manhood and birth of daughters' in L. Butler (ed.), Listen my son: Wisdom to help African American fathers, pp. 73-82, Abingdon, Nashville.

Wimberly, E., 2011, 'Story telling and managing trauma: Health and spirituality at work,' Journal of Health Care for Poor and Underserved 22, 48-57. 